\title{
Achecklist of agaricoid russulaceous mushrooms from Jammu and Kashmir, India
}

\author{
Komal Verma*, S.A.J. Hashmi*, N.S. Atri** and Yash Pal Sharma* \\ *Department of Botany, University of Jammu, Jammu-180006 \\ **Department of Botany, Punjabi University, Patiala-147002 \\ Corresponding author's Email: yashdbm3@yahoo.co.in
}

(Submitted on August 13, 2019; Accepted on November 15, 2019)

\begin{abstract}
A literature based checklist of the family Russulaceae occurring in Jammu and Kashmir (J\& K), India is presented. It consists of 51 species of russulaceous mushrooms belonging to three genera viz., Russula, Lactarius and Lactifluus. Genus Russula is the most speciose rich (35 spp.), followed by Lactarius (12 spp.) and Lactifluus (4 spp.). This checklist provides a comprehensive data of the russulaceous mushrooms from J\& K.
\end{abstract}

KEYWORDS: Ectomycorrhizal, Inventory, Jammu, Kashmir Valley, Russulaceae.

\section{INTRODUCTION}

Fungal family Russulaceae, one of the 12 families recognized under the order Russulales, is well known for its ectomycorrhizal association with higher plants (Kirk et al., 2008). Being ectomycorrhizal, these mushrooms play a critical ecological role in terrestrial ecosystems through symbiotic association with higher plants. Initially, macrofungal species belonging to this family were placed with other gilled species in the order Agaricales. Subsequent microscopic, molecular and phylogenetic studies confirmed that these mushrooms form a distinct lineage and are now placed under a different order Russulales. Members of this family can be differentiated from all other gilled mushrooms by the anatomy of the cap and stipe tissue that is interspersed with a large number of spherical cells called sphaerocysts, which impart typical brittle consistency to these mushrooms (Arora, 1986). Furthermore, they are characterized by fleshy and often bright coloured fruiting bodies with prominent broad lamellae, absence of clamp connections and warted, light-coloured, amyloid spores that exhibit diverse types of exosporial ornamentation.

The family exhibits global distribution and is represented by more than 1900 species (Kirk, 2014). Amongst all the genera of family Russulaceae, Russula is the largest genus (ca.1100 spp.), followed by Lactarius (ca. 550 spp.) Lactifluus (ca. 120 spp.), Boidinia (13 spp.), Multifurca (6 spp.), Gloeopeniophorella (6 spp.) and Pseudoxenasma (1 species) (Lebel et et al., 2013; Kirk, 2014). Till 2016, 158 taxa of Russula, 83 taxa of Lactarius, 29 taxa of Lactifluus, 1 species each of Multifurca and Gloeopeniophorella and 2 species of Boidinia have been reported from India (Sharma et al., 2018).

The agaricoid genera (Russula, Lactarius, and Lactifluus) constitute $95 \%$ of the family Russulaceae. Members of Russula are characterised by bright coloured, brittle sporocarps while those of Lactarius and Lactifluus have latex exuding feature. These genera are cosmopolitan in distribution and are one of the main ectomycorrhizal symbionts in diverse vegetation types ranging from the rainforests to the boreal coniferous forests.

Pioneering work on the russulaceous mushrooms from Jammu and Kashmir was done by Berkeley $(1854,1876)$ who documented 8 Russula and 5 Lactarius species from the
Himalayan region. After a long gap, Watling and Gregory (1980) started the work on russulaceous mushrooms which was further carried out by Abraham et al. (1980, 1981, 1984), Abraham and Kaul (1985) and Watling and Abraham (1992). Majority of the work on russulaceous mushrooms of Jammu and Kashmir was done by Saini, Atri and coworkers (Saini and Atri, 1982, 1984, 1989, 1990, 1993; Saini et al., 1982, 1988, 1989; Atri and Saini 1986, 1988; Atri et al., 1993, 1994). A significant contribution to these mushrooms from Kashmir was made by Beig et al. (2008, 2011), Dar et al. (2009), Pala et al. (2012) and Itoo et al. (2013). A vast number of studies have been conducted from Jammu province on different aspects but the family Russulaceae in particular have not been sufficiently dealt with except for a few reports by Kumar and Sharma $(2011,2012)$. Recently, Kaur et al. (2014) and Kaur and Rather (2016) reported few Russula species from J\&K. The present paper provides comprehensive details of diversity of the family Russulaceae from the Jammu and Kashmir.

Jammu and Kashmir is predominantly a Himalayan landscape in the northwestern part of India. It has two geographically distinct regions viz., Jammu Province and Kashmir Province, each showing its unique geographical, climatic, demographic, biological and cultural characteristics. While Jammu is rich in subtropical flora, Kashmir Province is predominated by the temperate vegetation and alpine desert or dry cold desert flora, respectively. The major conifers include Pinus roxburghii, Cedrus deodara, Abies pindrow, A. spectabilis, Taxus walichiana and Picea smithiana while the broad-leaved evergreen forests are predominantly represented by Buxus wallichiana, Ilex dipyrena, Quercus semicapifolia, etc. and deciduous forests by Aesculus indica, Populus alba, Acer caesium, Viburnum spp., Salix spp., Alnus spp., etc. This diverse vegetation provides host to the members of the family Russulaceae as these are well known to form ectomycorrhizal associations with these plants.

\section{METHODS}

This checklist is based on the information gathered from published sources and the information retrieved from the literature including distribution, general habitat and edibility status of each taxon. Nomenclature used for each species was 
checked against the classification system provided on the Index Fungorum web site (http://www.indexfungorum.org/ names/names.asp) and MycoBank (www.mycobank.org). Names of some species reported in the cited publications have been replaced by currently accepted name. The checklist is prepared by compiling all the available data and is organized alphabetically.

\section{CHECKLIST}

\section{Genus Lactarius Pers.}

1.1 Lactarius angustifolius Hesler and A.H. Sm.

Habit and habitat: Humicolous, solitary, putatively ectomycorrhizal, with coniferous forest dominated by Cedrus deodara.

Locality: Gulmarg (J\&K).

Edibility: not edible.

Jammu and Kashmir (Atri and Saini, 1986; Saini and Atri, 1993; Atri etal., 1994).

\subsection{Lactarius deterrimus Gröger.}

Habit and habitat: Humicolous, solitary, putatively ectomycorrhizal with coniferous trees of Pinus wallichiana and Cedrus deodara.

Locality: Bhadarwah, Gulmarg and Tangmarg (J\&K).

Ediblity: not edible in the locality but reported edible in some parts of the world.

Jammu and Kashmir (Abraham et al., 1980; Kumar, 2009).

\subsection{Lactarius fuliginosus (Krapf) Fr.}

Habit and habitat: Humicolous, scattered, putatively ectomycorrhizal, association with Viburnum species.

Locality: Gulmarg (J\&K).

Edibility: not edible.

Jammu and Kashmir (Abraham and Kaul, 1985).

\subsection{Lactarius hepaticus Plowr.}

Habit and habitat: Humicolous, solitary to gregarious, scattered, putatively ectomycorrhizal in coniferous forests of Cedrus, Pinus and Taxus.

Locality: Doodhpatheri(J\&K).

Edibility: not edible.

Jammu and Kashmir (Pala and Wani, 2014).

\subsection{Lactarius pubescens Fr.}

Habit and habitat: Humicolous, scattered or gregarious, putatively ectomycorrhizal in mixed forests under Betula.

Locality: Rajouri (J\&K).

Edibility: not edible, considered poisonous.

Jammu and Kashmir (Atri and Saini, 1986; Atri et al., 1994; Anand etal., 2014).

\subsection{Lactarius spinosulus Quél.}

Habit and habitat: Humicolous, scattered, gregarious, putatively ectomycorrhizal in the forests of Pinus roxburghii and $P$. wallichiana.

Locality: Poonch, Gulmarg and Pahalgam (J\&K).

Edibility: not edible.

Jammu and Kashmir (Beig et al., 2008).
1.7 Lactarius scrobiculatus (Scop.) Fr.

Habit and habitat: Humicolous, solitary to gregarious, putatively ectomycorrhizal in coniferous forests.

Locality: Yusmarg and Gulmarg (J\&K).

Edibility: unknown, but have medicinal value.

Jammu and Kashmir (Watling and Gregory, 1980; Abraham et al., 1980; Saini and Atri, 1984; Atri et al., 1994; Farooq et al., 2017).

1.8 Lactarius scrobiculatus var. canadensis (A.H.Sm.) Hesler and A.H.Sm.

Habit and habitat: Humicolous, solitary to gregarious, putatively ectomycorrhizal with conifers.

Locality: Tangmarg and Gulmarg (J\&K).

Edibility: unknown.

Jammu and Kashmir, (Atri and Saini, 1986, 1988; Atri et al., 1994).

\subsection{Lactarius subpurpureus Peck}

Habit and habitat: Humicolous, scattered to gregarious, putatively ectomycorrhizal with Viburnum species.

Locality: Gulmarg (J\&K).

Edibility: edible, medicinally important.

Jammu and Kashmir (Watling and Gregory, 1980; Saini and Atri, 1990).

1.10 Lactarius subisabellinus var. murrillianus (A.H.Sm. and Hesler) Hesler and A.H.Sm.

Habit and habitat: Humicolous, gregarious, putatively ectomycorrhizal, usually mixed with broad leaf forests.

Locality: Sonamarg (J\&K).

Edibility: not edible.

Jammu and Kashmir (Atri and Saini, 1986; Atri et al., 1994).

1.11 Lactarius uvidus (Fr.) Fr.

Habit and habitat: Humicolous, scattered, putatively ectomycorrhizal, under Salix.

Locality: Dachigam (J\&K).

Edibility: not edible.

Jammu and Kashmir (Watling and Gregory, 1980; Abraham etal., 1981).

1.12 Lactarius vellereus ( $\mathrm{Fr}$.) Fr.

Habit and habitat: Humicolous, solitary, putatively ectomycorrhizal with coniferous forests of Pinus wallichiana and Cedrus deodara.

Locality: Bhaderwah, Kalinag forest area (J\&K).

Edibility: not edible.

Jammu and Kashmir (Kumar and Sharma, 2011).

\section{Genus Lactifluus (Pers.) Roussel.}

2.1 Lactifluus controversus (Pers.) Kuntze

Habit and habitat: Humicolous, solitary to gregarious, putatively ectomycorrhizal with Salix alba.

Locality: Gulmarg and Tangmarg (J\&K).

Edibility: edible.

Jammu and Kashmir (Watling and Abraham 1992, Abraham et al., 1981, Atri et al., 1994 as Lactarius controversus Pers.). 
2.2 Lactifluus corrugis (Peck) Kuntze.

Habit and habitat: Humicolous, solitary, putatively ectomycorrhizal, under Quercus forest.

Locality: Gulmarg and Tangmarg (J\&K).

Edibility: not edible in Jammu and Kashmir but reported to be edible from some parts of the world.

Jammu and Kashmir (Atri and Saini, 1986; Saini and Atri, 1993 as Lactarius corrugis Peck).

\subsection{Lactifluus deliciosus (L.) Kuntze}

Habit and habitat: Humicolous, gregarious, putatively ectomycorrhizal in Pinus roxburghii forests.

Locality: Yusmarg and Mammer (J\&K).

Edibility: highly edible.

Jammu and Kashmir (Watling and Gregory, 1980; Abraham et al., 1980; Farooq et al., 2017 as Lactarius delicious (L.) Gray).

\subsection{Lactifluus volemus (Fr.) Kuntze}

Habit and habitat: Humicolous, solitary, ectomycorrhizal, forests of Pinus wallichiana and Cedrus deodara.

Locality: Bhaderwarh, (J\&K).

Edibility: not edible in the J\&K but reported to be edible in Uttarakhand.

Jammu and Kashmir (Kumar and Sharma, 2011 as Lactarius volemus ( $\mathrm{Fr}$.) $\mathrm{Fr}$.).

\section{Genus Russula Pers.}

3.1 Russula alutacea (Pers.) Fr.

Habit and habitat: Humicolous, scattered, putatively ectomycorrhizal with coniferous temperate forests dominated by Abies and deciduous forests of Salix.

Locality: Gulmarg (J\&K)

Edibility: not edible

Jammu and Kashmir (Berkeley, 1876).

\subsection{Russula aurea Pers.}

Habit and habitat: Humicolous, solitary to scattered, putatively ectomycorrhizal with Picea species.

Locality: Kellar, Gulmarg and Mammer (J\&K).

Edibility: edible having medicinal properties.

Jammu and Kashmir (Saini and Atri, 1984; Atri et al., 1994;

Dar et al., 2010; Farooq et al., 2017).

\subsection{Russula azurea Bres.}

Habit and habitat: Humicolous, scattered, putatively ectomycorrhizal with Quercus but also recorded occasionally under Picea.

Locality: Tangmarg (J\&K).

Edibility: not edible in $\mathrm{J} \& \mathrm{~K}$ but reported to be edible from some parts of the world.

Jammu and Kashmir (Saini and Atri, 1984; Saini et al., 1989).

\subsection{Russula alachuana Murr.}

Habit and habitat: Humicolous, solitary to scattered, putatively ectomycorrhizal associated with Quercus semecarpifolia.

Locality: Pahalgam and Gulmarg (J\&K).

Edibility: unknown.

Jammu and Kashmir (Saini and Atri, 1982).

\subsection{Russula albida Peck.}

Habit and habitat: Humicolous, solitary to scattered in small groups, putatively ectomycorrhizal mostly with Quercus semecarpifolia.

Locality: Baramulla (J\&K).

Edibility: unknown.

Jammu and Kashmir (Kaur and Rather, 2016).

\subsection{Russula annulata var. evanescens Kumar S and Sharma} YP.

Habit and habitat: Humicolous, scattered, putatively ectomycorrhizal with mixed forests of Alnus nepalensis and Juglans regia.

Locality: Dugga, Bhaderwah (J\&K).

Edibility: not edible.

Jammu and Kashmir (Kumar and Sharma, 2012).

3.7 Russula atropurpurea (Krombh.) Britzelm.

Habit and habitat: Humicolous, gregarious, putatively ectomycorrhizal, in coniferous forests of Pinus roxburghii and P.wallichiana.

Locality: Poonch, Hirpora (J\&K).

Edibility: not edible.

Jammu and Kashmir (Pala et al., 2012).

3.8 Russula aerugenia Lindblad.

Habit and habitat: Humicolous, putatively ectomycorrhizal, growing scattered, or gregariously under conifer trees or under Salix.

Locality: Hirpora (J\&K).

Edibility: edible.

Jammu and Kashmir (Pala et al., 2012).

\subsection{Russula brevipes Peck.}

Habit and habitat: Humicolous, putatively ectomycorrhizal, associated with Cedrus in coniferous to mixed temperate forests.

Locality: Pahalgam (J\&K).

Edibility: edible.

Jammu and Kashmir (Abraham et al., 1980; Watling and Gregory, 1980).

3.10. Russula cyanoxantha (Schaeff.) Fr.

Habit and habitat: Humicolous, solitary to scattered, putatively ectomycorrhizal, coniferous forests of Pinus wallichiana and Cedrus deodara.

Locality: Bhaderwah, Hirpora, Chenani, Patnitop and Sanasar (J\&K).

Edibility: not edible but edible in certain parts of the world.

Jammu and Kashmir (Kumar and Sharma 2012, Pala et al., 2012).

\subsection{Russula delica Fr.}

Humicolous, scattered, putatively ectomycorrhizal under Pinus.

Locality: Hirpora, Patnitop and Sanasar (J\&K).

Edibility: edible.

Jammu and Kashmir (Saini and Atri, 1984; Saini et al., 1988; Dar et al., 2009; Pala et al., 2012). 
3.12. Russula densifolia Secr. ex Gillet

Habit and habitat: Humicolous, putatively ectomycorrhizal, in association with species of Cedrus, Picea and Quercus in deciduous to mixed temperate forests.

Locality: Gulmarg, Sonamarg (J\&K).

Edibility: not edible.

Jammu and Kashmir (Watling and Gregory, 1980; Abraham et al., 1981; Atri and Saini, 1986; Atri et al., 1994).

3.13 Russula emetica (Schaeff.) Pers.

Habit and habitat: Humicolous, scattered, putatively ectomycorrhizal in coniferous forests.

Locality: Aru, Hirpora (J\&K).

Edibility: not edible.

Jammu and Kashmir (Beig et al., 2011; Pala et al., 2012).

3.14. Russula foetens Pers.

Habit and habitat: Humicolous, gregarious, putatively ectomycorrhizal, under coniferous forests.

Locality: Gulmarg, Pahalgam (J\&K).

Edibility: edible.

Jammu and Kashmir (Saini and Atri, 1984).

3.15. Russula firmula Jul. Schäff.

Habit and habitat: Humicolous, scattered, putatively ectomycorrhizal, with coniferous forests dominated by Abies. Locality: Gulmarg and Pahalgam (J\&K).

Edibility: not edible.

Jammu and Kashmir (Watling and Gregory, 1980; Itoo et al., 2013; Farooq et al., 2017).

3.16. Russula fragrantissima Romagn.

Habit and habitat: Humicolous, solitary, scattered in putatively ectomycorrhizal association with coniferous forests dominated by Abies.

Locality: Pahalgam(J\&K).

Edibility: not edible.

Jammu and Kashmir (Watling and Gregory, 1980).

\subsection{Russula fragilis $\mathrm{Fr}$.}

Habit and habitat: Humicolous, putatively ectomycorrhizal, generally scattered under both coniferous and broad leaved trees. Locality: Chadoora, Budgam (J\&K).

Edibility: not edible.

Jammu and Kashmir (Pala et al., 2011).

\subsection{Russula lepida Fr.}

Habit and habitat: Humicolous, solitary to scattered, putatively ectomycorrhizal under Pinus wallichiana and Cedrus deodara.

Locality: Pahalgam, Bhaderwah and Kishtwar (J\&K).

Edible: not edible.

Jammu and Kashmir (Atri and Saini, 1986; Saini et al., 1989; Kumar and Sharma, 2012).

\subsection{Russula lutea (Huds.) Gray}

Habit and habitat: Humicolous, common, gregarious, putatively ectomycorrhizal, under the canopy of Cedrus deodara and Abies trees during autumn season.

Locality: Gulmarg and Bandipora(J\&K).
Edibility: edible.

Jammu and Kashmir (Beig et al., 2008).

3.20. Russula nauseosa (Pers.) Fr.

Habit and habitat: Humicolous, scattered, putatively ectomycorrhizal with Pinus.

Locality: Gulmarg (J\&K).

Edibility: edible.

Jammu and Kashmir (Watling and Gregory, 1980; Abraham etal., 1980).

3.21. Russula nauseosa var. atropurpurea Allesch.

Habit and habitat: Humicolous, putatively in ectomycorrhizal association with Viburnum.

Locality: Pahalgam and Tangmarg (J\&K).

Edibility: unknown.

Jammu and Kashmir (Watling and Gregory, 1980).

\subsection{Russula nigricans $\mathrm{Fr}$.}

Habit and habitat: Humicolous, gregarious, scattered, putatively in ectomycorrhizal association with species of Quercus and Cedrus in coniferous, deciduous and mixed temperate forests.

Locality: Gulmarg and Sonamarg (J\&K).

Edibility: not edible.

Jammu and Kashmir (Saini and Atri, 1984; Saini et al., 1988).

3.23. Russula nobilis Velen.

Humicolous, scattered, putatively ectomycorrhizal under broad leaf forest dominated by Quercus species.

Locality: Hirpora wildlife sanctuary (J\&K).

Edibility: Poisonous.

Jammu and Kashmir (Pala et al., 2012).

3.24. Russula paludosa Britzelm.

Habit and habitat: Humicolous, scattered in coniferdominated forests under the canopy of Pinus wallichiana, putatively ectomycorrhizal.

Locality: Tangmarg J\&K).

Edibility: edible but easily mistaken with Russula emetica .

Jammu and Kashmir (Dar et al., 2009).

\subsection{Russula puellaris Fr.}

Habit and habitat: Humicolous, solitary to scattered, putatively ectomycorrhizal with Pinus wallichiana and Cedrus deodara.

Locality: Bhaderwah (J\&K).

Edibility: not edible

Jammu and Kashmir (Kumar and Sharma, 2012).

3.26. Russula persicina Krombh.

Habit and habitat: Humicolous, solitary to scattered, putatively ecotmycorrhizal in mixed forest dominated with Salixalba.

Locality: Sarband, Dachigam (J\&K).

Edibility: not edible.

Jammu and Kashmir (Watling and Gregory, 1980).

3.27. Russula rosea Pers.

Habit and habitat: Humicolous, putatively ectomycorrhizal, 
scattered, under coniferous forests.

Locality: Patnitop, Sanasar and Gulmarg (J\&K).

Edibility: not edible.

Jammu and Kashmir (Atri and Saini, 1986; Saini et al., 1989;

Kumar and Sharma, 2012).

\subsection{Russula rubicunda Quél.}

Habit and habitat: Humicolous, solitary, scattered, in putatively ectomycorrhizal association with Viburnum.

Locality: Tangmarg (J\&K).

Edibility: not edible.

Jammu and Kashmir (Watling and Gregory, 1980).

\subsection{Russula sanguinea (Bull.) Fr.}

Habit and habitat: Humicolous, scattered, putatively ectomycorrhizal with confers.

Locality: Gulmarg (J\&K).

Edibility: not edible.

Jammu and Kashmir (Watling and Gregory, 1980).

\subsection{Russula stuntzii Grund.}

Humicolous, solitary, putatively ectomycorrhizal in mixed forest.

Locality: Baramulla (J\&K).

Edibility: not edible but considered edible in some parts of the world.

Jammu and Kashmir(Kaur et al., 2014).

\subsection{Russula sardonia Fr.}

Habit and habitat: Humicolous, scattered, putatively ecotmycorrhizal with Abies pindrow.

Locality: Babareshi, Baramulla (J\&K).

Edibility: not edible.

Jammu and Kashmir(Beig et al., 2011).

\subsection{Russula tuberculosa R. Heim}

Habit and habitat: Humicolous, scattered, putatively ectomycorrhizal in coniferous forests of Pinus wallichiana and Cedrus deodara.

Locality: Bhaderwah, (J\&K).

Edibility: not edible.

Jammu and Kashmir (Kumar and Sharma, 2012).

\subsection{Russula velutipes Velen.}

Habit and habitat: Humicolous, solitary, scattered, putatively ectomycorrhizal with coniferous forests.

Locality: Gulmarg and Tangmarg (J\&K).

Edibility: unknown.

Jammu and Kashmir (Saini et al., 1989).

\subsection{Russula veternosa $\mathrm{Fr}$.}

Habit and habitat: Humicolous, scattered, putatively ectomycorrhizal with Quercus species.

Locality: Sonamarg and Gulmarg (J\&K).

Edibility: not edible.

Jammu and Kashmir (Watling and Gregory, 1980).

\subsection{Russula xerampelina (Schaeff.) Fr}

Habit and habitat: Humicolous, solitary, rare, putatively ectomycorrhizal with species of Quercus in temperate deciduous forests.

Locality: Sonamarg and Gulmarg (J\&K).

Edibility: edible.

Jammu and Kashmir (Saini and Atri, 1984; Saini et al., 1988).

\section{CONCLUSIONS}

Jammu and Kashmir is one of the biodiversity rich regions of India owing to varied climatic conditions and topographical features. Several investigations related to fungal diversity especially mushrooms have been undertaken in the region, yet the literature does not reveal much on russulaceous members as only 51 species of the family have been reported from Jammu and Kashmir so far. Owing to rich hosts and habitats such as coniferous forests, species of Betula, Quercus, Viburnum, Salix etc, supporting mushroom growth, a large number of ectomycorrhizal russulaceous taxa may exist in this region but seemingly there is a considerable gap between the number of ectomycorrhizal russulaceous taxa actually existing in nature and the number of documented species. Therefore, extensive exploratory studies are ardently called for in different geographical locations of Jammu and Kashmir.

\section{ACKNOWLEDGEMENT}

The authors wish to thank University Grants Commission, New Delhi for providing financial support under UGC-SAP DRS-II and the Head, Department of Botany, University of Jammu, Jammu for laboratory facilities. The first author also acknowledges for the financial assistance received from UGC in the form of JRF.

\section{REFERENCES}

Abraham, S.P., Kachroo, J.L. and Kaul, T.N. 1980. Fleshy fungi of Gulmarg Forest-1. Kavaka 8: 29-39.

Abraham, S.P. and Kaul, T.N. 1985. Larger fungi from Upsala Kashmir III. Kavaka 13: 77-81.

Abraham, S.P., Kaul, T.N. and Kachroo, J.L. 1981. Larger Fungi from Kashmir I. Kavaka 9: 35-43.

Abraham, S.P., Kaul, T.N. and Kachroo, J.L. 1984. Larger fungi from KashmirII. Kavaka 12: 41-48.

Anand, N., Mathur. A. and Chowdhary P.N. 2014. First report on survey of macrofungal biodiversity in Rajouri district (J\&K), India. World Journal of Pharmacy and Pharmaceutical Sciences. 3: 1385-1402.

Arora, D. 1986. Mushrooms demystified. A Comprehensive guide to the fleshy fungi. Ten Press: 959.

Atri, N.S., Saini, M.K. and Saini, S.S. 1994. Indian Russulaceae Roze a check list. In: Current Researches in Plant Sciences (Sarma, T.A., M.K. Saini and S.S. Saini eds.). pp. 81-93. Bishen Singh Mahendra Pal Singh, Dehradun, India.

Atri, N.S., Saini, M.K., Saini, S.S. and Gupta, A.K. 1993. Systematic studies on russulaceous fungi The genus Lactarius Pers. J. Indian Bot. Soc. 72: 155-158.

Atri, N.S. and Saini, S.S. 1986. Further contribution on the studies of North-West Himalayan Russulaceae. 
Geobios New Reports 5: 100-105.

Atri, N.S. and Saini, S.S. 1988. Studies on Lactarius Pers. The subgenus Piperities (Fr.) Kauff. Kavaka 16: 1319.

Beig, M. A., Dar, G. H., Ganai, N. A. and Khan, N. A. 2008. Mycorrhizal biodiversity in Kashmir forests and some new records of macrofungi from J\&K state. Appl. Biol.Res. 10: 26-30.

Beig, M.A., Dar, G.H., Khan, N. A. and Ganai, N.A. 2011. Seasonal production of epigeal fungal sporocarps in mixed and pure fir (Abies pindrow) strands in Kashmir forests. Journal of Agricultural Technology 7: 1375-1387.

Berkeley, M.J. 1854. Decades XLIXLIII. Indian Fungi. Hooker's J. Bot. 6: 129-143.

Berkeley, M.J. 1876. Three fungi from Kashmir. Grevillea 4: 137-138.

Dar, G.H., Beig, M.A. and Ganai, N.A. 2009. Hitherto unrecorded macrofungi from India. Appl. Biol. Res. 11: 59-62.

Dar, G.H., Ganai N.A., Beig M.A. and Ahanagar, F.A. 2010. Biodiversity of macrofungi from conifer dominated forests of Kashmir, India. Journal of Mycology and Plant Pathology 40:169-171.

Farooq, R., Shah, M.A. and Reshi, Z.A. 2017. Morphological and molecular characterization of some mushrooms in Kashmir Himalayan forests. International Conference on Recent Innovations in Science, Agriculture, Engineering and Management, ISBN 978-93-86171-80-1335-342.

Index Fungorum 2019. http:\\indexfungorum.org names\names.asp.

Itoo, Z.A., Reshi, Z.A and Andrabi, K.I. 2013. Characterization and identification of Russula firmula and Russula postiana from Himalayan moist temperate forests of Kashmir. Afr. J. Biotechnol. 12: 3643-3647.

Kaur, M. and Rather, H.A. 2016. Records of agarics: New to Jammu and Kashmir. Journal on New Biological Reports 5(3): 165-169.

Kaur, M., Rather, H.A. and Malik, N.A. 2014. Rough spored agarics from India New Records. Journal on New Biological Reports 3(1): 44-51.

Kirk, P.M. 2014. Species Fungorum (Version October, 2014). In: Species 2000 and ITIS Catalogue of Life. Species 2000 and ITIS Retrieved 2014-10-30.

Kirk, P.M., Cannon, P.F., Minte D.W. R and Stalpers, J.A. 2008. Dictionary of the Fungi. $10^{\text {th }}$ ed. CABI, Wallingford, UK.

Kumar, S. 2009. Taxonomic and ethnomycological studies of fleshy fungi in some regions of district Doda $(J \& K)$. $\mathrm{Ph}$.D. Thesis, University of Jammu, Jammu.
Kumar, S. and Sharma, Y.P. 2011. Diversity of wild mushrooms from Jammu and Kashmir (India). Proceedings of the 7th International Conference on Mushroom Biology and Mushroom Products (ICNBMP7), France, pp.568-579.

Kumar, S. and Sharma, Y.P. 2012: The macrofungi of Jammu and Kashmir Russula species. Mushroom Res. 21(2): 111-116.

Lebel, T., Dunk, C.W. and May, T.W. 2013. Rediscovery of Multifurca stenophylla (Berk.) T. Lebel, C.W. Dunk and T.W. May comb. nov. (Russulaceae) from Australia. Mycol.Prog. 12(3): 497-504.

Mycobank 2019. www.mycobank.org.

Pala, S.A. and Wani, A.H. 2014. Some hitherto unreported macrofungal species from coniferous forests of Kashmir Himalaya, India. Mushroom Res. 23(1): 5-13.

Pala, S.A, Wani A.H and Bhat M.Y. 2011. Six hitherto unreported Basidiomycetic macrofungi from Kashmir Himalayas. Nusantara Bioscience 3(2): 92-97.

Pala, S.A., Wani, A.H. and Mir, R.A. 2012. Diversity of macrofungal genus Russula and Amanita in Hirpora Wildlife Sanctuary, Southern Kashmir Himalayas. Biodiversitas 13: 65-71.

Saini, S.S. and Atri, N.S. 1982. North Indian Agaricales I. Indian Phytopath. 35: 265-272.

Saini, S.S. and Atri, N.S. 1984. Studies on NorthWest Himalayan Russulaceae. Geobios New Reports. 3:4-6.

Saini, S.S. and Atri, N.S. 1989. North Indian Agaricales XI. Section Russula Pers. in India. J. Mycol. Plant Pathol.19(1): 44-49.

Saini, S.S. and Atri, N.S. 1990. Two noteworthy taxa of Lactarius Pers. from India. J. Indian Bot. Soc. 69: 475-476.

Saini, S.S. and Atri, N.S. 1993. Studies on genus Lactarius from India. Indian Phytopathol. 46 (4): 360-364.

Saini S.S., Atri N.S. and Bhupal, M. 1988. North Indian Agaricales V. Indian Phytopathol.41: 622-625.

Saini S.S., Atri N.S. and Saini, M.K. 1989. North Indian Agaricales VI. J. Indian Bot. Soc. 68: 205-208.

Saini S.S., Atri N.S. and Singer, R. 1982. North Indian Agaricales II. Sydowia 35: 236-241.

Sharma, S, Atri N.S., Saini, M.K. and Verma, B. 2018. Catalogue of russulaceous mushrooms of India. Nova Hedwigia 106 (34): 357-401.

Watling, R. and Abraham, S.P. 1992. Ectomycorrhizal fungi of Kashmir forests. Mycorrhiza 2: 81-87.

Watling, R. and Gregory, N.M. 1980. Larger fungi from Kashmir. Nova Hedwigia 32 (23): 493-564. 